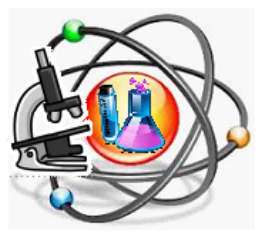

OPEN ACCESS ISSN 2540-9859 (online)

Edited by: Nur Efendi

${ }^{*}$ Correspondence:

Suyidno Suyidno suyidno_pfis@ulm.ac.id

Received: 15-10-2020 Accepted: 19-11-2020 Published: 30-11-2020

Citation:

Arsyad Z, Wati M and Suyidno S (2020) The Effectiveness of the Module Static Fluid with Authentic Learning to Train Students' Problem-Solving Skills. Science Education Journal (SEJ).

doi: 10.21070/sej.v4i2.1017

\section{The Effectiveness of the Module Static Fluid with Authentic Learning to Train Students' Problem-Solving Skills}

\author{
Zakiah Arsyad, Mustika Wati, Suyidno Suyidno* \\ Fakultas Keguruan dan IImu Pendidikan, Universitas Lambung Mangkurat, Indonesia
}

Authentic learning includes the necessary foundation in learning physics. However, the limitations of the physics module based on authentic learning have an impact on the common problem-solving skills of students. Therefore, the purpose of this study is to analyze the effectiveness of a static fluid module with authentic learning to practice student problem-solving skills. This research is research and development using the 4-D model (Define, Design, Develop, Disseminate). Class trials using one group pre-test and post-test design. The subjects of the research trial were 33 students of class XB SMA in Banjarmasin. The data were obtained through tests of problem-solving skills. The results showed that the module was effective because the results of Mann Whitney test were sig. $=0.00$; means there is a significant increase in problem-solving skills. Also, the students' problem-solving skills were in the very good category. Thus, a static fluid module with authentic learning is effective for practicing student problem-solving skills

\section{Keywords: Authentic Learning, Modules, Problem-solving Skills}

Autentik learning termasuk pondasi dasar dalam belajar fisika. Namun, keterbatasan modul fisika berbasis autentik learning berdampak pada rendahnya keterampilan pemecahan masalah siswa. Maka dari itu, tujuan penelitian ini adalah menganalisis efektifitas modul fluida statis bermuatan pembelajaran otentik untuk melatihkan keterampilan pemecahan masalah siswa. Penelitian ini adalah penelitian dan pengembangan dengan menggunakan model 4-D (Define, Design, Develop, Disseminate). Uji coba kelas menggunakan one group pre-test and post-test design. Subjek uji coba adalah 33 siswa kelas XB SMA di Banjarmasin. Data diperoleh melalui tes keterampilan pemecahan masalah. Hasil penelitian menunjukkan bahwa modul termasuk efektif karena hasil uji mann whitney diperoleh sig. $=0,00$; berarti ada peningkatan keterampilan pemecahan masalah secara signifikan. Selain itu, keterampilan pemecahan masalah siswa dalam kategori sangat baik. Dengan demikian, modul fluida statis bermuatan pembelajaran otentik adalah efektif untuk melatihkan keterampilan pemecahan masalah siswa.

Kata kunci: Pembelajaran Otentik, Modul, Keterampilan Pemecahan Masalah 


\section{INTRODUCTION}

High school graduates should master conceptual, factual, procedural, and metacognitive knowledge at the detailed, technical, specific, complicated, and complex levels where students can relate their experience to everyday life with the hope that students can solve problems (Kemendikbud (2016)). Students are expected to be able to link their experience with authentic facts and have problem-solving skills based on their knowledge. Problem-solving skills are a skill to get solutions to problems that include a critical, logical and systematic thinking process using the knowledge they have (Hidayat et al. (2017); Sujarwanto et al. (2014); Titin et al. (2018); Wardani (2015)). One of the lessons that involve real problems is authentic learning because its can reflect problem-solving carried out by students and is connected to the realities in the daily lives of students (Romadhaningsih (2014); Rusman (2017)). Physics needs to be taught with an authentic approach because physics concepts are closely related to facts in everyday life. Solving physics problems requires abstract thinking that is inseparable from conceptual knowledge that requires shadows to describe an object or event related to physics (Refiana et al. (2016)). Examples of authentic physics learning are the use of the concept of swamp water, Martapura river, jukung, riam kanan dams, and so on.

Science is presented with the hope that students can understand and master the science concepts and implement scientific methods based on scientific attitudes to solve the problems they face (Sambada (2012)). Physics is related to problemsolving because physics examines the concepts that exist in everyday life, so solving physics problems requires problemsolving skills (Kahar and Layn (2018)). Students who are trained to solve problems will be more analytical in making decisions and be more careful in solving problems in their lives (Thersia et al. (2019)). Students need to have problemsolving to solve physics problems and problems in their daily life. Therefore, learning physics requires infrastructure in the learning process where these facilities have continuity between the subject matter and the daily life activities of students in their environment and can practice their problem-solving skills (Armiah (2016)). The teacher plays a significant role in achieving goals in learning, including as a facilitator (Habibi et al. (2017)). So the excellent teacher provides lessons with the right media to practice problem-solving skills of students.

The research results of Azizah (2017) found students still find it challenging to solve problems because $32 \%$ of students have difficulty learning physics in solving problems. $26 \%$ have difficulty understanding formulas and concepts. $18 \%$ have difficulty using formulas or equations in questions. $17 \%$ have difficulty in analyzing pictures and graphics. It also $7 \%$ difficulty in providing conclusions about the material being studied. The results of interviews reinforce this by researchers with students at senior high school in Banjarmasin that they still have difficulty understanding physics material and solving physics problems. It can be seen from the test results with the material that students have learned, students' problem-solving skills are still low. The average aspect of identifying problems is 10.75 with a lousy category, planning strategies with an average of 3.87 categorized not right, implementing the process with an average of 7.25 is classified as not useful and evaluating the solution with a score of 0 is categorized as not applicable. The test results show that there are still many students who do not answer questions using the problem-solving stage, and no one even evaluates the solution. Students feel physics material is challenging to understand. Teachers rarely associate physics learning material with activities that students often encounter in environment. The teacher only teaches physics material through power points so that students exclusively rely on notebooks. Books available in the library are minimal; students also do not have handbooks to study at home and have never used other teaching materials such as modules.

The problems that have been described can be overcome by providing learning learners with varied teaching materials, namely modules containing authentic learning that can train students' problem-solving skills. Modules are a form of teaching materials that are carefully and systematically arranged in which everything is needed in a planned learning process and is designed to help students master specific learning objectiv (Astuti et al. (2019) ). Authentic learning is a learning approach that allows students to explore and discuss meaningful concepts and relationships involving real problems and projects that are relevant to them (Romadhaningsih (2014)). Modules containing authentic learning are systematic teaching materials, involving real issues in everyday life that are related to students. The advantages of authentic learning are that it can facilitate students in applying the material they learn in real practice, allow students to hone their creative and critical thinking skills through solving a problem and encourage students' metacognitive abilities (Rahmawati and Sukaesih (2014)). Linking static fluid material with events that occur in everyday life, especially in Banjarmasin, will make it easier for students to imagine the relationship between static fluid material and its application.

Understanding the concepts and motivation of students in learning can increase with modules containing authentic learning because to be able to solve problems, students must first understand the idea (Amanah et al. (2017)). The authentic learning-based enrichment module on dynamic fluid subjects can increase understanding of the concepts and motivation of students to learn (Armiah (2016)). Lifting local wisdom or daily reality in learning can develop character and also problem-solving skills with problem-solving strategies that are taken from problems in the environment of students (Titin et al. (2018)). Titin et al. (2018) esearch results concluded that local wisdom-based learning could improve students' problem-solving skills. The solution to poor problemsolving skills is to provide learning media that can train students' problem-solving skills (Fitriyani et al. (2019)). Learning based on local wisdom or learning that contains facts in the daily lives of students can practice and improve problemsolving skills. Authentic learning makes the lessons learned 
more meaningful. It strengthens the bonds of thought so that students can understand problems, develop new and unique solutions to solve significant problems in their lives (Elliot et al. (2007)).

Based on these descriptions, the main objective of this research is to analyze the effectiveness of static fluid modules with authentic learning in training students' problem-solving skills. Indicators of problem-solving skills taught in this study are identifying problems, planning strategy, implementing the plan, and evaluating solutions.

\section{METHODOLOGY}

This research is research and development (Research \& Development) and its used the 4-D model (Define, Design, Develop, Disseminate) by (Thiagarajan et al. (1974)). The Define stage is carried out by analyzing the curriculum, examining the characteristics of students, exploring the material and deciding goals. At the design stage, the module is done by adjusting the material content framework from the results of the curriculum analysis. The Develop stage is carried out by validating or assessing the feasibility of product design by experts in their fields. The disseminate stage includes the socialization of products from the development of learning and their use in real class trials to test their effectiveness (Azizah (2017)).

Before the problem-solving test, a static fluid module with authentic learning has been developed by researchers. It has gone through a validation test by the validator, namely two experts and one academic to obtain the module's validity and reliability values. The validity of the module is 3.40 , with a reliability of 0.98 , which means that the static fluid module with authentic learning is very valid and reliable. Reliability means the extent to which the measured results can be trusted (Matondang (2009)). It means that the evaluation by the three validators of this module has a high level of confidence. The results of the validity of this module are by the opinion of Gazali (2016)), which explains that the module shows validity or can be used in trials if the minimum validity number is valid. A good instrument should measure correctly means it is valid and consistent or is called reliable (Murti (2011)). So, it can be said that this module is valid and reliable. Thus, modules containing authentic learning that has been developed can be used in classroom learning as a learning resource for students.

The trial design used pre-experimental with one group pretest post-test design: $\mathrm{O}^{1} \mathrm{X} \mathrm{O}^{2}$ with 30 students of class $\mathrm{XB}$ at senior high school ini Banjarmasin. Product testing is carried out through a procedure by providing a pre-test $(\mathrm{O} 1)$ in the form of a problem-solving skill test to students, then carrying out learning $(\mathrm{X})$ using the developed module. Education is carried out in four meetings. The first and second meetings were held face-to-face in class, while the third and fourth meetings were conducted online using the What Sapp application and zoom. Students are trained to solve problems at each meeting through questions according to indicators, namely: (1) iden- tifying problems; (2) planning strategy; (3) implementing the design; and (4) evaluating solutions. After the learning ended, the post-test (O2) was carried out; students returned to work on the same problem-solving skills test as the pre-test questions. The data on the results of the problem-solving skills test were analyzed according to the score on the assessment grid, then the value of each problem-solving was calculated using percentages. The criteria then interpret the value or analysis score of the achievement of problem-solving skills obtained at each stage in Table 1.

[Table 1 about here.]

\section{RESULTS AND DISCUSSION}

The effectiveness of the static fluid module with authentic learning describes the level of achievement of problem-solving. It can through problem-solving skills tests, including problem identification, planning strategies, implementing strategies, and evaluating solutions. The results of the achievement of problem-solving are presented in Figure $\mathbf{1}$.

[Figure 1 about here.]

The graph above shows the pre-test score of students' problem-solving skills as a whole is in the wrong category, meaning that most of the students working on the questions are not by the problem-solving indicators yet. The post-test score after the implementation of the problem-solving skills module as a whole is in a perfect category. Students begin to be skilled in solving problems, meaning that the module is successful in practicing the problem-solving skills of students. The achievement of problem-solving skills is achieved from the pre-test to post-test scores. An example of one of the students' pre-test and post-test answers is in Figures 2 and 3.

\section{[Figure 2 about here.]}

The pre-test answer (Figure 2) shows that students did not answer the questions according to the problem-solving skills indicator. Students immediately write down the calculation without identifying, planning solutions and evaluating solutions.

[Figure 3 about here.]

The post-test answer (Figure 3) shows that students have answered the questions according to the indicators of problemsolving skills. Students identify problems by writing down what is known or asked in the questions, planning strategies by writing down the equations to be used, implementing procedures by performing mathematical calculations and evaluating solutions by rewriting the correct answers and units according to the concept.

The data on the achievement of students' problem-solving skills showed that the overall pre-test results were still in the bad category. The stages of identifying problems, planning strategies, implementing strategies and evaluating solutions are 
categorized as evil. In the pre-test, some students did not write down the answers at all; some only wrote numbers and calculations that were incorrect and without using the problemsolving stage. The cause of the incomplete indicator is due to the absence of learning resources that train students' problemsolving skills. Students are not presented with authentic learning. Students still have difficulty understanding the lesson and do not know that the physics material they are learning is related to everyday life. Students' problem-solving skills are still low. These results are consistent with the results of the initial study, the problem-solving skills of students of senior high school in Banjarmasin are still soft because the aspects of identifying problems, planning strategies, implementing strategies and evaluating solutions are categorized as not useful. It is also in line with Azizah (2017) that students still find it challenging to solve problems.

The post-test results after the implementation of learning using modules with authentic learning as a whole were categorized as very good because all stages of problem-solving were classified as very good. Students begin to be skilled in solving problems because they have been able to work on questions according to the problem-solving stages. Students identify issues by writing known or asked questions, but there are still students who are wrong in converting units. Students also write down the equations that will be used in implementing the strategy. However, there are still students who do not write down the equations in detail, only write the equations for the last stage in the calculation and immediately calculate them in the equation. It is because during learning the material is more focused on the experiment, the questions that are trained are only C3 questions. Students have been able to carry out the strategy; they calculate mathematically to get the desired results. Still, some students enter numbers without changing the units; first, some students are not accurate in calculating so that the calculation results are not correct. It is because some students enter the wrong numbers because of errors in confirming the units and some claim that they still have difficulty calculating numbers in decimal form. Students have been able to evaluate solutions by checking companies and writing the right answers according to the concepts applied to the questions. Still, some students do not assess solutions, and some are evaluating solutions by writing answers and units, but the answers are written are incorrect due to calculations wrong. It is because some students enter the wrong numbers because of errors in confirming the teams and some claim that they still have difficulty calculating numbers in decimal form.

Modules containing authentic learning play a significant role in training students' problem-solving skills, apart from the availability of sample questions, guided exercises, advanced training and competency tests. This module also presents material explanations based on everyday life and problems. It too authentic so that students. It is easier to understand and is interested in learning. It according to the theory which explains that modules are containing authentic learning. It can make students' understanding of concepts and learning motivation increase were to be able to solve problems; they must first understand the idea (Amanah et al. (2017)). Here is one cover design, the material with authentic learning and guided exercises in Figures 4, 5 and 6.

\section{[Figure 4 about here.]}

[Figure 5 about here.]

[Figure 6 about here.]

Students are trained in solving problems because they are often taught through modules containing authentic learning. Students see the stages of problem-solving in the sample questions. When working on guided practice questions, they fill in the answers according to the solving steps at the points provided in the guided practice column, so that when doing advanced exercises and competency tests they are used to working on problems with solving stages problem. The developed module containing authentic learning is supported by a theory which explains that authentic learning reflects the task and also problem solving carried out by students related to everyday life (Rusman (2017)).

In the post-test results, almost all students scored above Minimum Completeness Criteria (MCC) of school, there were only two people who scored below the MCC, where the MCC at the school was 70. It is because students started late in doing the assessment. They could not work on the questions maximally also did not have time to work on the last two problems. In contrast, the only students had difficulty in calculating with decimal numbers so that some of the questions up to the stage of implementing the strategy were not done thoroughly and students did not do the next step, namely evaluating solutions. The number of students who can get scores above the MCC is due to the role of the developed module and the efforts of the students themselves, even one student can get a perfect score. It shows that the static fluid module with authentic learning can practice the problem-solving skills of students. In line with Elliot et al. (2007) theory which explains that with authentic learning, students can have the ability to understand complex problems, develop new and unique solutions to solve problems. The obstacle in the post-test is the difficulty of the teacher in supervising students in taking problem-solving skills tests because the post-test is done online.

The achievement of students' problem-solving skills after implementing learning with modules containing authentic learning as a whole is very good. It is confirmed by the results of the Mann Whitney test, which is a non-parametric test. The results are presented in Table 2 .

\section{[Table 2 about here.]}

The results of the Mann Whitney test (Table 2) show sig value of 0.00 . This sig value is less than 0.05 , which means that there is a significant difference in the students' scores between the pre-test and the post-test. Given that $\mathrm{Z}$ is worth -6.663 ; then there is an increase from the pre-test results to the post-test 
students. Thus, the use of learning-loaded modules has a significant impact on improving students' problem-solving skills. The non-parametric test with the Mann Whitney test was carried out because the students' pre-test and post-test scores were not normally distributed, this was because there were too many extreme values of students in one data set. From the results of effectiveness, the modules developed are effective. Modules are useful because the desired objectives are achieved. The module performs the valid category because it is by the theory which explains that effectiveness is a measure of the success or failure of achieving predetermined goals and is also a relationship between results and expected things, activities are useful if the process is carried out to accomplish the goals (Sucahyowati (2017)).

Overall, the average value of the achievement of students' problem-solving skills in the pre-test was in the wrong category, while the post-test was very good so that the module was useful. This module is said to be effective. The problem-solving stages such as identifying problems, planning strategies, implementing strategies and evaluating solutions are included in the right and excellent categories, besides that there is an increase from the results of the pre-test to the post-test of students. Thus, the module with this outstanding category can be used in the learning process to practice the problem-solving skills of stu-

\section{REFERENCES}

Amanah et al. (2017). KEMAMPUAN PEMECAHAN MASALAH DALAM FISIKA DENGAN PEMBELAJARAN GENERATIF BERBANTUAN SCAFFOLDING DAN ADVANCE ORGANIZER. Jurnal Pendidikan Fisika dan Teknologi 3, 8484. doi: 10.29303 /jpft.v3i1.334.

Armiah (2016). Pengembangan Modul Fisika Berbasis Kearifan Lokal untuk Melatihkan Karakter Kayuh Baimbai pada Materi Fluida. Skripsi. Fakultas Keguruan dan Ilmu Pendidikan. Universitas Lambung Mangkurat: Banjarmasin.

Astuti, I. A. D., Putra, I. Y., and Bhakti, Y. B. (2019). Developing Practicum Module of Particle Dynamics Based on Scientific Methods to Improve Students' Science Process Skills. Scientiae Educatia 7, 183-183. doi: 10.24235/sc.educatia.v7i2. 2513.

Azizah (2017). Lembar Kerja Peserta Didik Materi Aritmatika Sosial dengan Model Pengembangan Thiagrajan. Jurnal Matematika dan Pendidikan Matematika 1, 63-72.

Elliot et al. (2007). Authentic Learning Transforms Student and Teacher Success. Journal of Authentic Learning 4, 34-42.

Fitriyani et al. (2019). Pengaruh LKS Kolaboratif Pada Model Pembelajaran Berbasis Masalah Terhadap Keterampilan Pemecahan Masalah Fisika Siswa SMA. Berkala Ilmiah Pendidikan Fisika 7, 71-71. doi: 10.20527/bipf.v7i2.6026.

Gazali (2016). Pengembangan bahan ajar matematika untuk siswa SMP berdasarkan teori belajar ausubel. PYTHAGORAS: Jurnal Pendidikan Matematika 11, 182182. doi: $10.21831 /$ pg.v11i2.10644.

Habibi et al. (2017). Pengembangan Perangkat Pembelajaran IPA Fisika Berorientasi Kemampuan Pemecahan Masalah Menggunakan Model Pengajaran Langsung Pada Pokok Bahasan Tekanan. Berkala Ilmiah Pendidikan Fisika 5, 1-17.

Hidayat et al. (2017). Pengembangan Instrumen Tes Keterampilan Pemecahan Masalah pada Materi Getaran, Gelombang, dan Bunyi. Jurnal Penelitian \& Pengembangan Pendidikan Fisika 3, 157-166. doi: 10.21009/1.03206.

Kahar and Layn (2018). Analisis Respon Peserta Didik dalam Implementasi Lembar Kerja Berorientasi Pemecahan Masalah. Berkala Ilmiah Pendidikan Fisika 6, 292-292. doi: 10.20527/bipf.v6i3.5054.

Kemendikbud (2016). Peraturan Menteri Pendidikan dan Kebudayaan Nomor 20 Tahun 2016 Tentang Standar Kompetensi Lulusan Pendidikan dasar dan Menengah (Jakarta: Menteri Pendidikan dan Kebudayaan Republik Indonesia). dents.

\section{CONCLUSION}

The application of a static fluid module with authentic learning in schools is useful in practising the problem-solving skills of students in the very good category and shows a significant improvement. Students are trained to solve problems according to the stages of problem-solving skills. The fundamental implication of this research is that the static fluid module with authentic learning can be used in learning in the world of education. However, the obstacle in this study is the lack of prior knowledge of students about how to convert units and calculate decimal numbers which have an impact on the problemsolving skills are not maximal.

\section{ACKNOWLEDGEMENTS}

The award was conveyed to the Physics Education Program, Faculty of Teacher Training and Education, Lambung Mangkurat University and SMK Isfi Banjarmasin for the financial support and facilities for this research.

Matondang (2009). Validitas dan Reliabilitas Suatu Instrumen Penelitian. Jurnal Tabularasa PPS UNIMED 6, 87-97.

Murti (2011). Validitas dan Reliabilitas Pengukuran. Matrikulasi Program Studi Dektoral, 1-19.

Rahmawati and Sukaesih (2014). Pengaruh Pembelajaran Autentik Berbasis BTLBerkarakter Metode Seven Jump terhadap Keterampilan Proses Sains. Lembaran Ilmu Kependidikan 43, 57-70.

Refiana et al. (2016). Meningkatkan Kemampuan Analisis Siswa Kelas X MS3 SMAN 2 Banjarmasin Pada Materi Gerak Melingkar Melalui Pengajaran Langsung Bermetode Pemecahan Masalah. Berkala Ilmiah Pendidikan Fisika 4, 6464. doi: 10.20527/bipf.v4i1.1048.

Romadhaningsih, B. (2014). Peran Pembelajaran Otentik (Authentic Learning) Melalui Lubang Resapan Biopori Terhadap Pemahaman Siswa Tentang Mitigasi Bencana Banjir Pada Mata Pelajaran IPS-Geografi Siswa Kelas VII Di SMP Muhammadiyah 4 Surakarta. Doctoral dissertation, Universitas Muhammadiyah Surakarta.

Rusman (2017). Belajar dan Pembelajaran Berorientasi Standar Proses Pendidikan. Jakarta: Kencana.

Sambada (2012). PERANAN KREATIVITAS SISWA TERHADAP KEMAMPUAN MEMECAHKAN MASALAH FISIKA DALAM PEMBELAJARAN KONTEKSTUAL. Jurnal Penelitian Fisika dan Aplikasinya (JPFA) 2, 37-37. doi: 10.26740/ jpfa.v2n2.p37-47.

Sucahyowati (2017). Manajemen Sebuah Pengantar (Jakarta: Wilis).

Sujarwanto et al. (2014). Kemampuan Pemecahan Masalah Fisika Pada Modeling Instrution Pada Siswa SMA Kelas XI. Jurnal Pendidikan IPA Indenesia 3, 66-78.

Thersia et al. (2019). Meningkatkan Kemampuan Pemecahan Masalah Melalui Pendekatan Somatis Auditori Visual Intelektual (SAVI) dengan Model Pengajaran Langsung. Berkala Ilmiah Pendidikan Fisika 7, 19-19. doi: 10.20527/bipf.v7i1. 5638.

Thiagarajan, S., Sammel, D., and Semmel, M. I. (1974). Instructional development for training teachers of exceptional children (A Sourcebook: Bloomington).

Titin, T., Yokhebed, Y., et al. (2018). PENINGKATAN KETERAMPILAN PEMECAHAN MASALAH (PROBLEM SOLVING) CALON GURU BIOLOGI MELALUI PEMBELAJARAN BERBASIS KEARIFAN LOKAL. Jurnal Pendidikan Matematika dan IPA 9, 77-86. doi: 10.26418/jpmipa.v9i1.23701.

Wardani (2015). Peningkatan Keterampilan Pemecahan Masalah Matematika SMP Melalui Strategi Discovery Learning. 
Conflict of Interest Statement: The authors declare that the research was conducted in the absence of any commercial or financial relationships that could be construed as a potential conflict of interest.

Copyright $\odot 2020$ Arsyad, Wati and Suyidno. This is an open-access article distributed under the terms of the Creative Commons Attribution License (CC BY). The use, distribution or reproduction in other forums is permitted, provided the original author(s) and the copyright owner(s) are credited and that the original publication in this journal is cited, in accordance with accepted academic practice. No use, distribution or reproduction is permitted which does not comply with these terms. 


\section{LIST OF TABLES}

1 Criteria for Problem-Solving Skills . . . . . . . . . . . . . . . . . . . . . . . . . . 120

2 Results of Mann Whitney of Problem Solving 
TABLE 1 | Criteria for Problem-Solving Skills

\begin{tabular}{ll} 
Value & Criteria \\
$P>80$ & Very good \\
$60<P \leq 80$ & good \\
$40<P \leq 60$ & Good enough \\
$20<P \leq 40$ & Not good \\
$P \leq 20$ & very not good \\
\hline
\end{tabular}

$\mathrm{P} \leq 20 \quad$ very not good 
TABLE 2 | Results of Mann Whitney of Problem Solving

\begin{tabular}{|c|c|}
\hline & Pre-test \\
\hline Mann-Whitney U & .000 \\
\hline Wilcoxon W & 465.000 \\
\hline Z & -6.663 \\
\hline Asymp, Sig. (2-talled) & .000 \\
\hline
\end{tabular}




\section{LIST OF FIGURES}

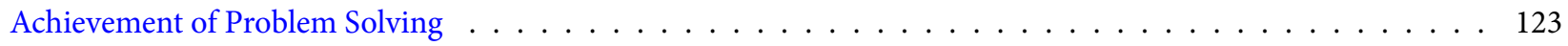

Students' Pre-test Answers . . . . . . . . . . . . . . . . . . . . . . . . . . . . . 124

Students' Post-test Answers . . . . . . . . . . . . . . . . . . . . . . . . . . . 125

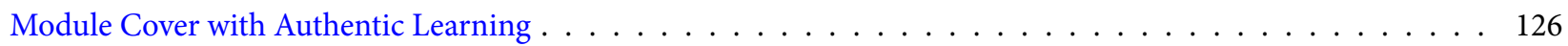

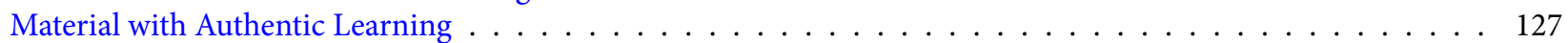

Guided Exercise . . . . . . . . . . . . . . . . . . . . . . . . . . . 128 


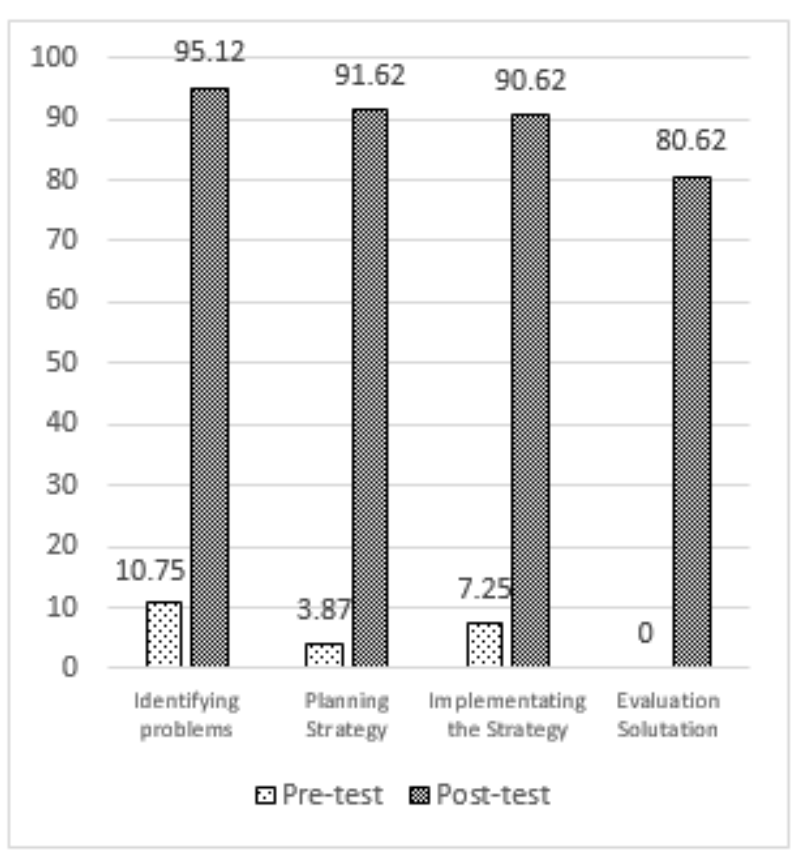

FIGURE 1 | Achievement of Problem Solving 


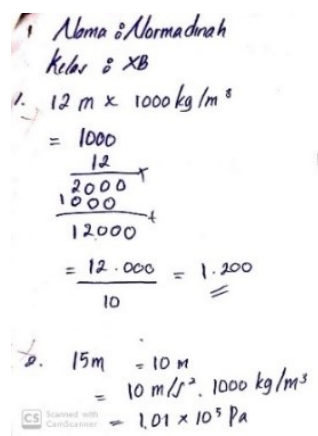

FIGURE 2 | Students' Pre-test Answers 


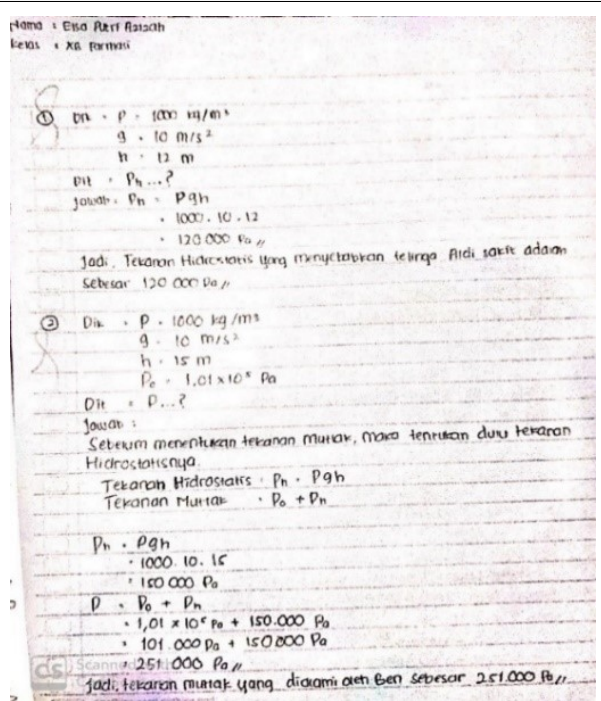




\section{Zakiah Arsyad}

\section{MODUL PEMBELAJARAN}

\section{FLUIDA STATIS}

\section{Bermuatan Pembelajaran Otentik}

kelas X SMK

Pembimbing:

Dr. Mustíka Wati, M.Sc

Dr. Suyidno, M.Pd
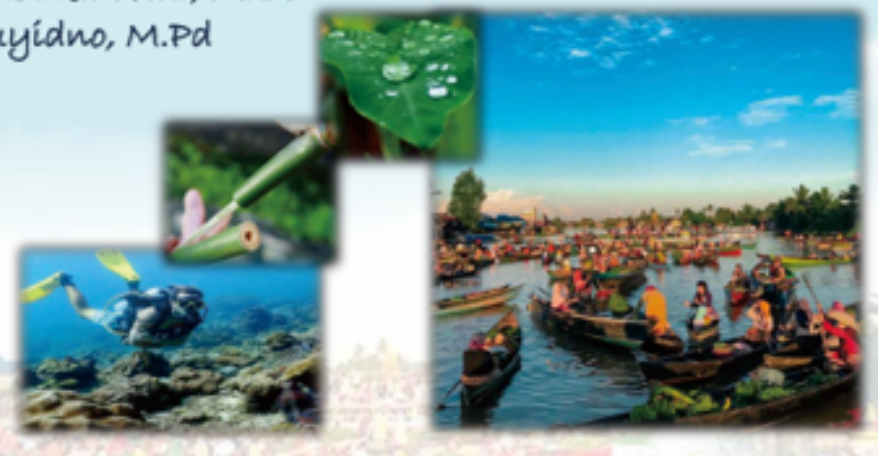

Program Studi Pendidikan Fisika

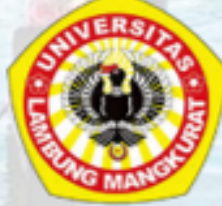
Fakultas Keguruan dan IImu Pendidikan Jurusan Pendidikan Matematika dan IPA Universitas Lmbung Mangkurat 


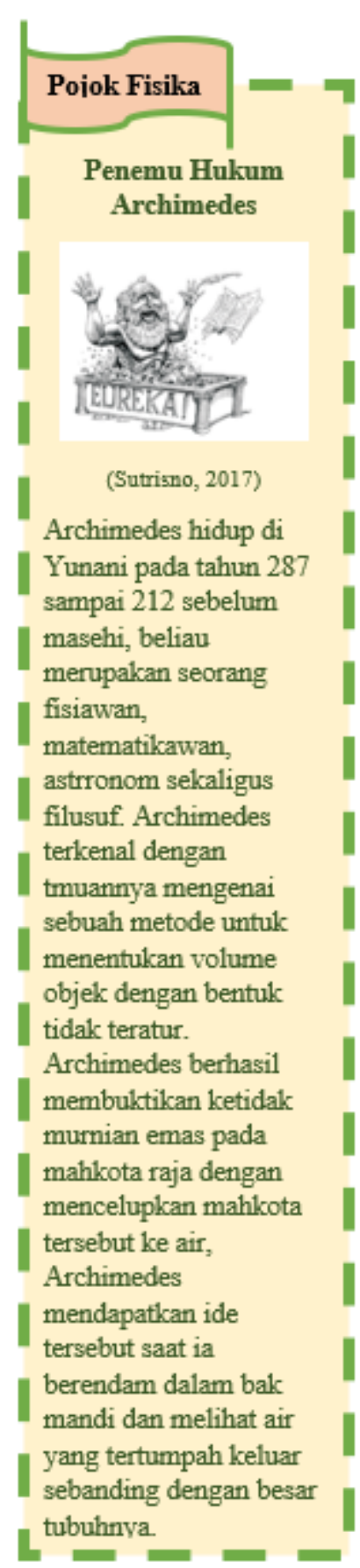

\section{A.Hukum Archimedes}

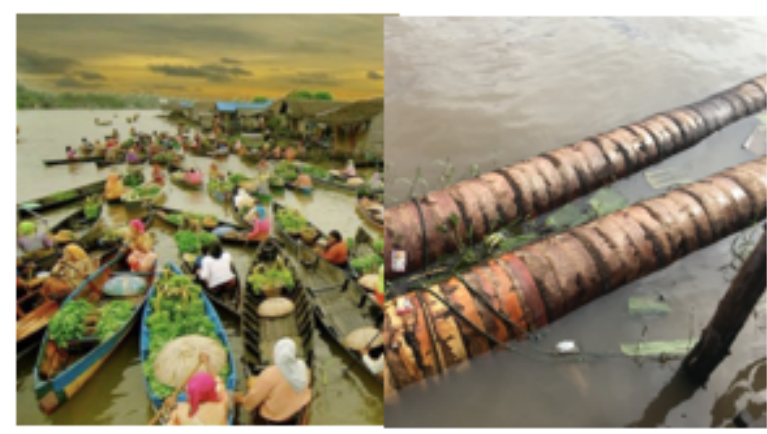

(a)

Gambar 3.1 (a) Pasar terapung, (b) Batang pohon rumbia (Lissa, 2019)

Pernahkah kamu berpikir mengapa jukung dan batang pohon rumbia yang besar dan berat tidak tenggelam? Gambar di atas memperlihatkan jukung yang membawa berbagai makanan dan batang pohon rumbia mengapung di sungai. Sebenarnya berat benda di dalam air tetap, tetapi air memberikan gaya yang arahnya ke atas sehingga benda seolah-olah menjadi ringan. Hal itulah yang disebut sebagai berat semu.

Benda dalam hal ini jukung dan batang pohon yang dimasukkan ke air akan mendapat gaya ke atas sehingga kehilangan sebagian beratnya. Gaya ke atas inilah yang disebut sebagai gaya apung. Gaya apung muncul sebagai akibat dari pertambahan tekanan oleh zat cair karena kedalamannya. Besarnya gaya apung yang diterima, nilainya sama dengan berat air yang dipindahkan oleh benda tersebut dan memiliki arah gaya yang bertolak belakang. Arah gaya berat ke bawah, sedangkan arah gaya apung ke atas. Inilah yang menyebaban jukung dan batang pohon rumbia tidak tenggelam. Sesuai dengan bunyi Hukum Archimedes.

FIGURE 5 | Material with Authentic Learning 


\section{Latihan Terbimbing 3.1 Hukum \\ Archimedes}

Lili ingin memasukkan batu hias ke dalam aquarium yang berisi penuh air. Jika berat air yang dipindahkan (tumpah) setelah batu hias dimasukkan adalah sebesar $2 \mathrm{~N}$ dan massa jenis air yaitu $1000 \mathrm{~kg} / \mathrm{m}^{3}$. Berapakah volume batu hias yang tercelup ke dalam aquarium? Percepatan gravitasi bumi $\left(g=10 \mathrm{~m} / \mathrm{s}^{2}\right)$

Diketahui:

$$
W_{\text {air }}=\ldots \ldots \ldots \ldots . \quad \rho=\ldots \ldots \ldots \ldots . . \quad g=
$$

Ditanyakan: ?

Jawaban:

\section{- Berat air yang tumpah}

Persamaannya :

\section{- Gaya apung}

Persamaanya :

Dimana berat air yang tumpah sama dengan gaya apung batu sehingga dapat ditulis

Jadi, volume batu hias yang tercelup ke dalam aquarium adalah sebesar

\section{Banua Kita}

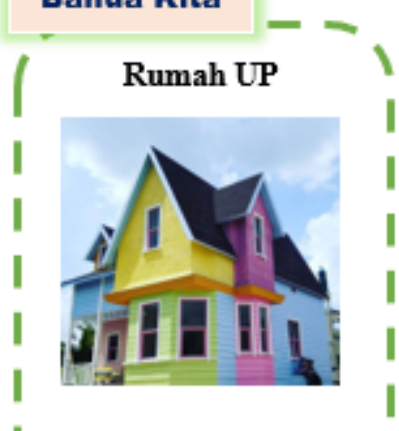

Masih ingatkah kamu dengan film kartun UP yang

menceritakan kakek

tua yang memiliki rumah dan rumah tersebut terbang karena balon-balon gas. Rumah yang terisnpirasi dari film kartun UP sekarang ada di Banjarmasin tepatnya di Jalan Agatis II, Kayutangi, Banjarmasin.

I Walaupun rumah UP Banjarmasin tidak terbang seperti pada

film, namun rumah

UP ini ramai

dikunjungi karena

| warna warni cat pada rumah tersebut

sehingga sangat pas

| untuk dijadikan tempat berfoto

dengan hanya

I mengeluarkan biaya sebesar 10.000

I rupiah. 